\title{
Obstacles to Women's Higher Education in Nepal: A Critical Review of Policies and Practices
}

\author{
- Ganga Laxmi Bhandari \\ Lecturer, Mahendra Ratna Campus, Tahachal
}

\begin{abstract}
This article critically reviews the theoretical and practical issues posing barrier to women for pursuing higher education and reaching professionally leading position in the Nepalese education sector. This article is based on the secondary resources such as cases and materials available in the public domain, and writer's own experiences. The study concludes that Nepali women are facing numerous obstacles in all sectors, from household to public institution as well as in the education sector. However, the nature and intensity of obstacles differ among certain ethnic groups.
\end{abstract}

Keywords/terms: Professional development, patriarchy, women empowerment, stereotypes

\section{Background}

Nepali women face numerous obstacles on their way to higher education and to their professional development. Compared to men, these obstacles prevent them from reaching leadership positions in their profession. Over the years, policies and laws have been enacted against the obstacles, which basically are discriminations and violence against girls and women. However, the implementation of policies continues to be of a serious concern due largely to the patriarchal world view that is not only deeply entrenched in Nepali society and culture but is also influential in the public domain, including in educational institutions.

This article is a comparative analysis of the situation and scope of difficulties a woman has to face in her pursuit of education and professional development in the education sector in Nepal. The analysis also focuses on opportunities that are available now as well as the difficulties that inhere within the opportunities. The comparison is between my schooldays and present days. In the process, I will engage relevant literatures, particularly those dealing with such concepts as 'rights', 'empowerment' and 'equality' to which the topic is related. Moreover, the promises and assurances made 
to-date by way of laws and policies; the gap in the enforcement of these policies and laws; and, the horrific consequences of the lack of proper implementation of the laws and policies also will be covered.

'Professional development,' which is referenced and dealt here and there in this write up, is defined narrowly to mean options and opportunities available for a girl and women to gain higher education and other opportunities necessary to lead and steer teaching and other educational activities at higher educational level. To enrich the debate, I have cited a few societal and cultural women-specific obstacles to show how they harm women as who they are and how it structurally affects their educational pursuit. I have used the theory of patriarchy to define the problem and also to explore solution.

The sources of data of this article are my own experiences and published materials, such as the data of female enrolment in graduate and postgraduate studies; legal and policy commitments of the government of Nepal, and external critic of the performance of the government vis-à-vis its policies and laws; and, women-specific materials of non-governmental sectors. My informal conversations with women educationists have also been treated as an important source for writing this article.

\section{Situation then and now}

I was the first girl from Kurule Tenupa, a remote village of Dhankuta at the border of Dhankuta and Panchthar districts, to finish the School Leaving Certificate (SLC) examination in 2043 BS. The closest Secondary School for us then was eight hours walk from my village Kurule Tenupa. We were two girls, to appear in the SLC examination of the year and, I was the only girl to overcome the examination among seven students.

During my school days, there were hardly seven or eight female teachers in the two schools (out of three schools I studied). There was no female teacher at my first school Kurule Tenupa where I completed my lower secondary education. Other two schools had few female teachers. When I was admitted in grade VIII in Damak, Jhapa I saw that woman can also be a teacher and that was a kind of new experience and excitement for a small child of 12 years brought up in a remote hilly area where the concept of women teacher was only a dream. To my knowledge, none of them had completed higher education because they used to teach in lower grades. Even as a child I used 
to be amazed why there are very few 'miss' - we used to address a female teacher as miss in those schools like now.

In hindsight, it can be claimed the unavailability of schools in villages then was a barrier for women to join schools and continue their education to develop themselves as a teacher. My colleagues were not as lucky as I was to have a father as a teacher committed to seeing his daughter pursue education. He helped me move to places of convenience for pursuing higher education.

Now, in the last 31 years the scenario has been changed. Almost every village has at least one high school. Over 35,200 schools currently enroll 7.4 million children in basic and secondary education, with girls constituting some 51 percent (3.8 million) at the time of enrolment (MoE, 2016a). In the School Sector Development Plan, 2016-2023, the Government of Nepal has committed itself to further improving the school programme (basic and secondary education) with added focus on what it calls "the three pillars: access, inclusion, and quality" (MoE, 2016b, p. 8). The first of the two pillars relate to girls.

The past years have seen progress even at higher education. In 1980, higher education used to be the sole prerogative of males, with 81 percent of them getting enrolled in higher education institutions (UGC, 2012). In 2016, 1,369 higher education institutions (community, constituent and private campuses) enrolled 407,904 students, together with 212,567 female students. Thirty-six years down the line, data shows that the traditionally held 'male' domination is no longer the same these days as people can speculate. The male enrolment rate is sliding down to 48 percent and that of females is found going up to 52 percent at Bachelor's level (UGC, 2016a, p. 15). More interesting, as Table 1 shows, the faculty of education stands out as the top faculty to enroll girls. 
Obstacles to Women's Higher Education in Nepal: A Critical Review...

\begin{tabular}{|l|l|l|l|l|}
\hline \multicolumn{6}{|l|}{ Table 1: Number of students by faculty } \\
\hline Faculty & Female & Male & Total & Share (\%) \\
\hline Buddhism & 87 & 154 & 241 & 0.06 \\
\hline Education & 83709 & 45276 & 128985 & 31.62 \\
\hline Engineering & 3390 & 12496 & 15886 & 3.89 \\
\hline HSS & 23476 & 22615 & 46091 & 11.3 \\
\hline Law & 1576 & 3349 & 4925 & 1.21 \\
\hline Management & 79311 & 82204 & 161515 & 39.6 \\
\hline Medicine & 12047 & 9197 & 21244 & 5.21 \\
\hline SandT & 8912 & 19815 & 28727 & 7.04 \\
\hline Sanskrit & 59 & 231 & 290 & 0.07 \\
\hline Total & 212567 & 195337 & 407904 & 100 \\
\hline
\end{tabular}

Source: UGC, 2016a, p. 14

While these figures suggest a huge progress, female students do not seem to fair well as they move towards higher level of education. While female students outnumbered male students at the bachelor level by four percent, they lagged behind by five percent at the master's level, by a whopping 64 percent at the MPhil level and by 67 percent at the PhD level. Table 2 below shows a wider gender disparity in enrolment of students at higher levels (PGD and PhD). From this, we can speculate that there are obstacles on the way to attain higher education by women and, as a result, to develop professionally and engage their expertise.

\begin{tabular}{|l|l|l|l|l|}
\hline \multicolumn{6}{|l|}{ Table 2: Number of Students by Level of Study } \\
\hline Level & Female & Male & Total & Share (\%) \\
\hline Bachelor & 189534 & 166811 & 356345 & 87.36 \\
\hline Master & 22798 & 27724 & 50522 & 12.39 \\
\hline MPhil & 77 & 354 & 431 & 0.11 \\
\hline PGD & 76 & 29 & 105 & 0.03 \\
\hline PhD & 82 & 419 & 501 & 0.11 \\
\hline Total & 212567 & 195337 & 407904 & 100 \\
\hline
\end{tabular}

Source: UGC, 2016a, p. 15

\section{Enough rhetoric, disturbing reality}

Thirty-one years after completing my SLC examination, the opportunities for women to reach postgraduate level are at the same level as they were for 
women to join and complete intermediate level of study. This means, it took 31 years for us to break the obstacles to reach master's level. And there is a further long way to go to equip ourselves to reach leadership positions that require MPhil and $\mathrm{PhD}$ degrees. In a sense the obstacles that were on the way 31 years ago are still there on women's way to professional development. The nature, form and intensity of obstacles have, however, changed over the years.

At the rhetorical or policy level, there has been a significant progress. Four years after my SLC, Nepal ushered into democratic politics. The transformation was particularly appealing to women and marginalized communities, such as Dalits, religious minorities and even geographically marginalized areas. The 1992 Constitution for the first time in Nepal's constitutional history promised equality, in Article 11, between men and women and also provided for "special provisions for the protection and advancement of the interest of women..." (HIMALAYA, 1991, p. 22). The reference to 'special provision' in the article implicitly recognized that Nepali women did not have access and opportunity to develop themselves, hence special back up was needed.

The new polity was expected to reign in the historical exclusion and discrimination against women pervading in almost all walks of political and socio-economic life of Nepal institutionalized by the archaic interpretation of Hinduism, which the erstwhile constitution had protected as a state religion. The archaic interpretation of Hinduism, which is what we have been subjected to, not only denies women equality with men but also prescribes that women should be subordinate to men (Olivelle, 2005; Rambachan, n.d.). This patriarchal worldview was for long reinforced through education. Even after the 1990 Constitution providing for constitutional equality, no significant efforts were made to neutralize the patriarchal mindset and promote gender equality.

Immediately thereafter began the "People's War" by the Communist Party of Nepal/Maoist (CPN-M). One of its aims was to empower women and free them from the clutches of patriarchal violence and all other forms of social and cultural violence, as evident by the inclusion in their "forty-point demands" submitted to the government on 4 February 1996, nine days before the announcement of the launch of the "People's War," following, as the $19^{\text {th }}$ demand: "Patriarchal exploitation and discrimination against women should 
be stopped. Daughters should be allowed access to paternal property" (Thapa and Sijapati 2003, p. 214). And a significant number of women joined the "People's War," together with other marginalized communities hoping for freedom, equality and justice (Onesto, 2005, p. 9):

Many different sections of Nepalese society have been drawn to support the Maoists' fight against the government: the rural population wants land and development, women want equality and an end to oppressive feudal and patriarchal traditions, achieve these things as part of the overall revolutionary transformation of society......

Onesto (2005) may be right to argue that the Maoists' promise of equality and the end of feudal patriarchy inspired women to join them. However, the consequence of the "People's War" have not been better than any other armed conflict. It resulted in destruction and myriad forms of violence against women. Women suffered both directly and indirectly. They were killed, sexually abused, tortured and displaced. But, they were also made to bear additional socio-economic burden when their male members were killed or disappeared. As Lohani-Chalise (2008, p. 272-73) argues, "The Maoist People's War is not devoid of contradictions and complexities... women are suffering under insurgency and militarization, coupled with the stalled economic and development processes, speaks of a differently gendered and sexed situation..."

The Interim Constitution, 2007, which was promulgated after the end of the Maoist armed conflict devoted an article (Article 20) to enumerate specific rights for women, including the right against discrimination; right against physical, mental or other form of violence; right to reproductive health; and, right to equality in terms of ancestral property (UNDP, 2009, p. 72). In addition, the reference to women's inclusion and participation features prominently in relation to the formation of the constituent assembly, with a provision that at least one-third of women should be among those nominated for the constituent assembly. The Interim Constitution also mandates political parties to ensure women's participation in the organs of state.

The Constitution of Nepal 2015 (Secretariat of National Assembly, 2015) further adds to the list of rights, rights protection and gender equality guaranteed by the 2007 Interim Constitution. Noteworthy among them are 
the acquisition of citizenship in the name of mother (Article 12); the reaffirmation of equality regardless of gender in various provisions, such in terms of parental property and equal remuneration for the same work (Article 18); and the provision for high office bearers, particularly President and Vice President, and Speaker and Deputy Speaker to be from different sex (Articles 70 and 91 respectively).

National Women Commission, 2002, with itsconstitutional status (Article 252) has the responsibility for gender equality and women's empowerment. To this end, it is mandated to work out policies and programmes to promote women's welfare; carry out research on the status of implementation of welfare programmes and laws aimed at tackling societal violence and malpractices against women; to ensure that Nepal's policies and laws are in compliance with international standards; and recommend measures that need to be initiated, including law amendments, to address existing barriers (Secretariat of National Assembly, 2015). Over the years, a few laws dealing with specific issues have also been made, including the Gender Equality Act, 2006; the Human Trafficking and Transportation (Control) Act, 2007; and the Domestic Violence (Crime and Punishment) Act, 2009. Scores of other measures were initiated by both the government of Nepal and nongovernmental agencies, including international development partners of Nepal towards equality and women's empowerment (GESI Working Group, 2017). The Ministry of Education's School Sector Development Plan envisions Nepal's graduation "from the status of a Least Developed Country by the year 2022 and to reach the status of the middle-income country by 2030" (MoE, 2016b, p. 2).

These are by no means small achievements. Some of the provisions of the 2015 Constitution are even said to be more progressive than those in what is known as advanced countries. However, despite all these measures and promises, "girls and young women face numerous challenges in their everyday life, ranging from early marriage to psychological and sexual violence, fewer opportunities in workspace to societal traditions that ... place women on a lower rung" (Bhattarai, 2017).

Where the problem lies is in the practical implementation of these political or policy - commitments. In this respect, the following observation made, in 2011, by the United Nations Committee on the Elimination of Discrimination against Women (CEDAW) is instructive: 
The Committee is concerned that patriarchal attitudes and deeprooted stereotypes that discriminate against women remain entrenched in the social, cultural, religious, economic and political institutions and structures of Nepalese society and in the media. It is also concerned about the persistence of harmful traditional practices in the State party, such as child marriage, the dowry system, son preference, polygamy, widows accused of witchcraft, and such practices as chaupadi, jhuma, deuki and dhan-khaane (UN, 2011, p. 4).

As regards education, which is the main focus of this article, the CEDAW Committee, as is how it is known, observes the following:

While welcoming the overall increase in gender parity in primary and secondary education, the Committee is concerned about the minimal increase in female enrolment, the extremely high drop-out rate for girls, the urban/rural disparities in access to education and illiteracy rates, and the low literacy rate for female adults. The Committee is further concerned about the extremely low number of female teachers at all levels of education (UN, 2011, p. 7).

The CEDAW Committee made the remarks commenting on government of Nepal's report on the implementation of the provisions of the Convention on the Elimination of All Forms of Discrimination against Women, to which Nepal is a State Party, and, as such, is responsible for its implementation making laws and policies as necessary.

As the Committee rightly points out, significant promises have been made over the years in the form of policies, laws and even constitutional guarantee. However, there is stark inadequacy in terms of implementation of the political commitments, especially as regards addressing the problem of patriarchal attitudes.

Women from marginalized communities, such as Dalit, are further disadvantaged than other high-caste women. The Dalit women suffer double violence, both as a Dalit, hence 'untouchable' according to the Hindu caste system, and as a woman. According to a study, Dalit women fair less than national averages in most of indices, such as life expectancy, ownership of 
property, including land, literacy, education, health and sanitation, and employment (FEDO, 2017, p. 3).

The International Dalit Solidarity Network (IDSN) on its webpage brings to light the following disturbing fact as to the status of Dalit women and children:

Apart from being forced into the most demeaning jobs, Dalit women are extremely vulnerable to sexual exploitation and are often victims of trafficking and forced sexual labour... Dalit girls in general are trafficked to Indian brothels in increasing numbers and forced to work as prostitutes (IDSN, n.d.).

On 19 June 2018, The New York Times ran a story asking this damning question "Where a Taboo Is Leading to the Deaths of Young Girls" about chhaupadi, which is quite common in western communities of Nepal. It is a social practice in which women are separated from their family during their periods, and made to stay in unhygienic huts or cow sheds.

The question Gentleman (2018) asked in the article builds on his field study of affected women. His question is not just damning, it is also reflective of the fact that policy and legal provisions, whatever outstanding, do not make sense if there is no will or capacity to implement those policies and legal provisions.

Gauri Kumari Bayak was the spark of her village. Her strong voice echoed across the fields as she husked corn. When she walked down the road at a brisk clip, off to lead classes on birth control, many admired her self-confidence.

But last January, Ms. Bayak's lifeless body was carried up the hill, a stream of mourners bawling behind her. Her remains were burned, her dresses given away. The little hut where she was pressured to sequester herself during her menstrual period — and where she died - was smashed apart, erasing the last mark of another young life lost to a deadly superstition.

Each year, at least one woman or girl - often more - dies in these huts, from exposure to the cold, smoke inhalation or attacks by animals. Just this June, another young woman was found dead in a menstruation hut, bitten by a snake. Her 
family tried to cover up the death, the police said, by destroying the hut and quickly burying her body, but the authorities exhumed it and are investigating what happened.

People are aware of the harm of this deadly practice, as the article suggests. Yet, they are unable to rise to it fearful of the superstitious belief that a menstruating woman staying in her home with family members will bring one of the three or all of these sinister things to the house: "A tiger will come; the house will catch on fire; and, the head of the house will get sick."

To avoid these dangers to the house, family members and the head of the family, who is a male; women are forced to bear the brunt of this superstition, which thrives on the compound of ignorance (lack of education) and resultant poverty. The force of superstition gets irresistible because of patriarchal worldviews that, among others, portrays women as a weaker being and call for their submission to the strong, the men, in this case, for their safety, security and existence as a whole. Grown up with this submissive worldview, these women have no choice but to follow the cultural norm defined by men and die for it.

Our patriarchy is worse than other forms of it. In our case, it is a caste-based patriarchy. In each caste-group, patriarchy manifests differently. For example, among Brahmins, its influence may be less forceful than it is among Dalits, who find subjugated both by caste hierarchy as well as by patriarchal norms defined largely by high-caste Brahmins, who, having had exposure to Sanskrit texts, command authority over explaining them.

\section{Discussion of Key Points}

The promises offered by democratic politics at the start of the 1990s have remained practically unfulfilled with regards to women's equality and gender justice. It is not that nothing has happened. Policies have been formulated, laws have been enacted and some institutions have also been created aimed at empowering women. However, their implementation has been dismally minimal.

The mismatch between policy promises and practical delivery is nowhere starker than in women's education. The delay in creating educational opportunities for women has cost them dearly. It has robbed them of opportunities they need to develop their awareness, skills and expertise to 
question social stereotypes, fight cultural malpractices that harm them and nurture their potential. Ignorance about what is wrong and right has made them victims of numerous cultural malpractices.

Of late, there seems to be increased awareness among parents and guardians about educating their daughters and sisters. It is encouraging. However, these young women have not been able to go beyond master's level of education as the data presented above (Table 1 and Table 2) show. What this suggests is even for those who have somehow managed to join colleges/universities; the road to higher education that prepares them for leadership position is tough. Put differently, no enabling environment exists yet for Nepali women's professional growth to the point that they are able to reach a leadership position and demonstrate that they can be as good as men, if not better, to serve their society and country. And this happens despite laws and policies providing for safeguards, protections and other special measures of empowerment.

In my experience over the years, I have had an opportunity to interact with the women who have completed higher education and are professionally engaged as trainers, schoolteachers, administrators and professors. Among them, a few are in leadership positions, such as principals of schools and higher educational institutions. Interestingly, I have found all women-led schools and institutions comparatively better overall, neat and clean, disciplined and performing well. But the number of such women is very nominal. A striking majority cannot break the invisible glass ceiling.

Even for those who have somehow managed to break the glass ceiling, there is no level playing field to compete and excel. Women can do just as good as men, better than men in some cases, as experiences show, but are prevented from entering the race. Why is this so?

This 'why' needs to be critically interrogated and unpacked? Theoretically speaking, it is due to patriarchy, "a social system that is male-identified, male-controlled, male-centered" that gives value to "masculinity and masculine traits over femininity and feminine traits" (Becker, 1999, p. 2425) and debilitates women right from their upbringing and continues into various stages of life. The patriarchal worldview "builds on the ideology of 'the law of the father'" (Murray, 1995, p. 123) and institutionalizes norms and practices to keep women "subordinate in a number of ways" including 
through "discrimination, disregard, insult, control, exploitation, oppression, violence - within the family, at the place of work, in society" (Sultana, 2011, p. 7). To keep women subordinate and men superior, patriarchy can go to any extent, as Sultana's work further demonstrates.

Such as, son preference, discrimination against girls in food distribution, burden of household work on women and young girls, lack of educational opportunities for girls, lack of freedom and mobility for girls, wife battering, male control over women and girls, sexual harassment at workplace, lack of inheritance or property rights for women, male control over women's bodies and sexuality...

As long as the male priority, so central to patriarchy continues to be taken as normal, the denial and discrimination against girls and women exist. Such discrimintation will hamper their development of skills and so disturbs their talent and excellence in the professional markets including education. To follow this worldview, there is no harm in girls' dropout or them being behind in education, but is rather what it should be. Worryingly, this worldview is very strong even among educated parents.

The central obstacle to women's advancement is, therefore, the influence of patriarchy in their everyday life. During childhood, they are taught to be subservient, not being demanding, assertive and engaging. This childhood education blunts their curiosity to question and argue, and forces them to accept whatever is given or available. As the entire social structure is patterned after the patriarchal worldview, to argue theoretically, all institutions, including educational, are patterned after this mindset that does not support and encourage women. The failure of policies, proclamations and laws to yield results, which are the empowerment of women and them being able to march in equality with men, are a testimony of this fact.

All this throws up a few fundamental questions that should be earnestly demystified for a clear understanding of the obstacles. Why are the policies, laws and other efforts made to-date not yielding results? Why do discriminations continue despite constitutional and legal guarantees?

Lack of political will among policy makers and implementers, almost all of them being males, may be a justification for this glaring failure. There could be other reasons as well. And, this requires a more structured and robust study. It is high time that such a study was done, obstacles identified and 
prioritized, and solutions explored. It is high time that universities placed particular attention to such issues and themes. They cannot just be limited to one or two term papers.

\section{Conclusion}

Nepali women are facing numerous obstacles at all levels in their pursuit of education. The obstacles cut across all women of all class and communities. However, the nature and intensity of obstacles differ among certain castegroups. The Dalit women at the lowert rug of caste hierarchy are the worst hit.

Without women being empowered as equal as men, a new and equal society as envisioned by the 2015 Constitution of Nepal or as claimed by the School Sector Development Plan cannot be realized. To ensure women's empowerment, they should have unhindered access to education right from primary level to the highest level of education. This requires addressing all obstacles, patriarchy being the primary one, with due political will. This also requires special measures promised in the constitution and other policy documents to be implemented to address a particular need of women. Massive awareness campaigns against cultural malpractices can be the one. Special incentive packages for women who dared to rise against them can be another. The point is, there should be genuine proactive initiative on the part of the state as well as other non-state actors, such as non-governmental organisations.

To ensure professional equality in the education sector, and to create an enabling environment, the Government of Nepal and other concerned, including university administration, educational planners and implementers, should bring out a policy to encourage women to continue their higher education, put in place and implement strict legal regime to deal with discrimination or harassment against girls and women, both at home and in public places, including in educational institutions, and create women friendly environment right from basic to higher education levels.

For women to be professionally equal to men, they must be treated and respected as socially, politically and culturally equal at the university. Nepal has already achieved this equality at the rhetorical level. The challenge now is to translate that rhetoric into a practical reality by making higher education, particularly MPhil and $\mathrm{PhD}$, affordable and accessible to women. This may require an incentive system to be in place for women, such as special scholarship for women or a quota system. Educational planners and 
policy makers should take this seriously. Or else, we will continue to remain where we were three decades ago, and be subjected to world-wide humiliation because of the stories of the kind the New York Times has run.

There should be no room for ignorance and denial of education. Every effort should be made to reduce the influence of patriarchy, and laws against castebased discrimination be strongly enforced. Universities should engage these issues as a matter of educational importance. Malpractices and discriminations should be academically challenged. Only then, we will be able to create a society where everyone will be judged by merit but not just based on sex.

\section{References}

Becker, Mary. (1999). "Patriarchy and inequality: Towards a substantive feminism." University of Chicago Legal Forum: Vol. 1999: Issue 1, Article 3. Retrieved from: http://chicagounbound.uchicago.edu/uclf/ vol1999/iss1/3.

Bhattarai, Richa. (2017). "The long road to gender equality in Nepal." End Poverty in South Asia. Retrieved from: http://blogs.worldbank.org/ endpovertyinsouthasia/long-road-gender-equality-nepal.

FEDO (Feminist Dalit Organisation). (2017). Concerns of Dalit women in high level political forum- 2017 on sustainable development. Retrieved from https://www.womankind.org.uk/docs/default-source/ resources/ briefings/fedo-lobby-document.pdf?sfvrsn=0.

GESI Working Group. (2017). A common framework for gender equality and social inclusion. Nepal: Gender Equality and Social Inclusion Working Group. International Development Partners Group.

Gettleman, Jeffrey. (2018). "Where a taboo is leading to the deaths of young girls?" The New York Times, June 19, 2018. Retrieved from: https://www.nytimes.com/2018/06/19/world/asia/nepal-womenmenstruation-period.html.

HIMALA. (1991). "Constitution of the kingdom of Nepal VS 2047 (1990)". Himalaya: The Journal of the Association for Nepal and Himalayan Studies, vol. 11 no. 1, Article 6. Retrieved from http:// digitalcommons. macalester.edu/himalaya/vol11/iss1/6. 
IDSN (International Dalit Solidarity Network). (n.d.). Dalit women in Nepal. Retrieved from https://idsn.org/key-issues/dalit-women/dalit-women-innepal-2/.

Lohani-Chalise. (2008). Women and gender in the Maoist people's war in Nepal: Militarisation and dislocation. A dissertation submitted to the Graduate School-New Brunswick, Rutgers, The State University of New Jersey, in partial fulfillment of the requirements for the degree of Doctor of Philosophy.

MoE (Ministry of Education). (2016a). Education in figures 2016 at a glance. Kathmandu: MoE, Government of Nepal (Educational Information Management Section). Retrieved from http://moe.gov. $\mathrm{np} /$ article/711/nepal-education-in-figure-2016.html.

MoE (Ministry of Education). (2016b). School sector development plan, Nepal, 2016-2023. Kathmandu: MoE, Government of Nepal.

Murray, Mary. (1995). The law of the father? Patriarchy in the transition from feudalism to capitalism. London and New York: Routledge.

Olivelle, Patrick. (2005). Manu's code of law. Oxford and New York: Oxford University Press.

Onesto, Li. (2005). Dispatches from the people's war in Nepal. London: Pluto Press.

Rambachan, Anantanand. (n.d.). Hindu perspective. Retrieved from https:// www.sunypress.edu/pdf/60256.pdf.

Secretariat of National Assembly. (2015). Nepal's constitution 2015 (rev 2016). Constitute. Retrieved from https://constituteproject.org/ constitution/Nepal_2016.pdf?lang=en.

Sultana, Abeda. (2011). "Patriarchy and women's subordination: A theoretical analysis." Arts Faculty Journal, Vol. 4 (2010-2011).

Thapa, Deepak and Sijapati, Bandita. (2003). A kingdom undersSiege: Nepal's Maoist insurgency, 1996 to 2004. Kathmandu: Printhouse.

UGC (University Grants Commission). (2012). Education management information system - Report on Higher Education 2010/11. Bhaktapur: University Grants Commission. 
UGC (University Grants Commission). (2016). Education management information system - Report on Higher Education 2014/15. Bhaktapur: University Grants Commission.

UN. (2011). Concluding observations of the Committee on the Elimination of Discrimination against Women, CEDAW/C/NPL/CO/4-5. Retrieved from https://undocs.org/CEDAW/C/NPL/CO/4-5.

UNDP. (2009). The Interim constitution of Nepal, 2063 (2007). Kathmandu: United Nations Development Programme. 